\title{
Influence of Value, Knowledge, and Consumer Attitude of Consumer Willingness to Pay More
}

\author{
L.P.V.I. Perdanawati*, A.M. Adiandri, N.N. Sudiyani \\ Universitas Ngurah Rai \\ Bali, Indonesia \\ virraindah30@gmail.com
}

\begin{abstract}
The purpose of this study was to determine the effect of value, knowledge, and attitude of consumers towards consumers' willingness to pay more for the product for green consumerism. The participants involved in the study were 50 consumers who buy products in The Body Shop Bali. The study found that there is a significant influence between values, knowledge, and attitude of a consumer to willingness to pay more a consumer for environmentally green products.
\end{abstract}

Keywords-Consumer attitude; Value; Knowledge; Consumer Willingness

\section{INTRODUCTION}

Since the last few of decades, there has been a great increase in the level of awareness and knowledge of society through the importance of sustainability and natural ecosystems. Fears and threats in the community about the possibility of natural disasters and the environment will be threatened. However, it was not for the health of their life sustainability and descendant. The evidence has been represented by scientists and environmentalists stating that depletion of the ozone layer, global warming, air and water pollution has reached a dangerous level, reinforces the reason for the concern. Seeing such conditions, there emerges green consumerism in the society.

Green consumerism products are the actions of consumer awareness to get a decent, safe, and green product environment. The emergence of this awareness has also led some companies to implement environmental issues as one of the marketing strategies or commonly called as green marketing. Green marketing is the activity of the company products that are designed to meet and facilitate the needs or desires of consumers with the least impact on the natural environment [1]. Green marketing is an environmentally oriented marketing strategy that influences marketers in deciding policies [2]. Green marketing always intends to replace current needs and desires by minimizing the negative impact on the environment.

There are two main values that affect the con-sumer behavior, including individualistic orientation and collective orientation [3]. The individualistic orientation represents how much focus and dependence on himself. Judging from the description, the attitude of individualist oriented values is perceived as less supportive of environment's friendly attitude. Collective attitude, on the other hand, is the opposite of the individualist. This attitude is reflected by helping others and considering group goals more than individual goals. This collectivist consumer group will support an environmental-ly friendly program, and values that indicate safety are less significant in influencing the value held in maintaining environmental sustainability [4]

Consumer awareness in preserving the environment comes from their knowledge of the importance of creating healthy environment. In some cases, it was found that knowledge was significantly related to how consumers collect, organize, and evaluate in-formation [1]. Green community emerges a new term to identify environmentally friendly aspects of a product, namely Ecoliteracy, developed by [4]. One example is the concept of 4R (Reduce, Reuse, Recycle, and Re-cover) or symbols that illustrate that the products can be recycled. Ecoliteracy has a fairly close correlation with one's behavior and attitudes toward the environment lately.

Attitude is the consistent results in an environ-mentally purchasing decision [5]. Most stud-ies of ecological literature present two dominant attitudes that influence one's green consumerism behaviour. One of the attitude is the awareness of the importance of environmentally friendly attitude. The attitudes which support eco-friendly behavior ac-companied by respect for the environment are the stage where one will express concern for ecological issues [4].

The premium price is the price for paid and great-er that the price corresponding to the truth of the value of a product that indicates willingness to pay [3]. Price is the most valid information as an indicator of the quality of a product. The premi-um price of an item will automatically indicate the high quality products. Product quality in this case is determined on the measurement of objective quality and perceived quality. The objective quality is de-fined as a measurable and quantifiable attribute from within the product compared to a standard product that can be created. Meanwhile, perceived quality is defined as the consumer assessment of the superiority of a product.

Based on above explanation, many companies ap-ply international standards or better known with ISO-14000. ISO 14000 is an international standard in the company that provides assurance to producers and consumers by applying the system through a process that takes account of the rules environmental management measures conditions. The process of applying ISO 14000 includes eco-labeling activities interpreted as labeling 


\begin{tabular}{|l|l|l|}
\hline Variables & Beta & Sig \\
\hline $\mathrm{X} 1$ & 0.065 & 0.038 \\
\hline $\mathrm{X} 2$ & 0.709 & 0.010 \\
\hline $\mathrm{X} 3$ & 0.065 & 0.022 \\
\hline
\end{tabular}

activities in the form of symbol, attributes, or other forms of environmentally friendly products and services.

Some companies use green marketing as the key of their successful marketing strategies, such as The Body Shop [4]. The company is a pioneer of green marketing strategy applied in every product to promote the importance of preserving nature. The company is designed for consumers to get information about the importance of preserving the environment. Media, such as information cards, window displays, and video about the environment resulting in social impact are used to inform consumers about the impacts of production and purchase made. The company offers products with natural ingredients, environmentally friendly, and no animal testing. The $4 \mathrm{R}$ concepts is also included in the green production and conversation strategy undertaken by the company. Using the context of green production approach, the case study was conducted at The Body Shop in Bali, Indonesia.

\section{METHOD}

This study employed a quantitative method to ex-amine the hypothesis since the data is quantitative data. A questionnaire was administered to 50 consumers of Body Shop Bali. It contains questions about the value, knowledge, and attitudes of consumers to consumers' willingness to pay more for the products. Data were analyzed using SPSS instruments using simultaneous $\mathrm{F}$ test, T-test Partial, and the coefficient of determination test.

\section{RESULTS AND DISCUSSION}

\section{A. Simultaneous F test}

F Test is conducted to find out how far the influence of the variable independent of the dependent variable simultaneously [6].

TABLE 1. SIMULTANEOUS F TEST.

\begin{tabular}{|l|l|l|l|}
\hline Model & F & Sig. \\
\hline \multirow{4}{*}{1} & Regression & 32.245 & $.000^{\mathrm{b}}$ \\
\cline { 2 - 4 } & Residual & & \\
\cline { 2 - 4 } & Total & & \\
\hline
\end{tabular}

The analysis shows that the significant value of $0,000<0,005$ and $F$ arithmetics is 32.245 . Simultane-ously, the variable of attitude, value, and knowledge have positive and significant influence to willingness to pay more.Define abbreviations and acronyms the first time they are used in the text, even after they have been defined in the abstract. Abbreviations such as IEEE, SI, MKS, CGS, sc, dc, and rms do not have to be defined. Do not use abbreviations in the title or heads unless they are unavoidable.

\section{B. Partial T test}

T-test is done to find out how far the influence of independent variable explaining the variation of dependent variable.

TABLE 2. T-TEST.
The result of T-Test on value variable has signifi-cant value equal to $0.038<0.05$; knowledge has sig-nificant value equal to $0.010<005$; and attitude has significant value equal to $0.022<0.05$.

\section{Determination Test}

The determination test is used to measure how far the variation of independent variable affects the de-pendent variable.

TABLE 3. R SQUARE.

\begin{tabular}{|l|l|}
\hline R Square & Adjusted R Square \\
\hline .678 & .657 \\
\hline
\end{tabular}

Based on adjusted $\mathrm{R}$ square, the value of 0.657 with value (X1), knowledge (X2), and attitude (X3) is able to explain the variation in supply chain performance by $65.7 \%$.

Based on the table, it can be seen that value, knowledge, and attitude simultaneously affect the willingness to pay more consumers for green environmental products. If the values, knowledge, and attitude in a person have upheld the interest of nature and environmental protection, they will be will-ing to spend some additional funds, to obtain products that are green consumerism. The variables of value, knowledge, and attitude can be said to complement each other because they can affect the willingness to pay more consumers.

The first hypothesis shows significant value to the desires of consumers to pay more. This indicates that the more the value of the product, the more the consumer to pay. Environmentally friendly products can be seen not only from the content of its products but also from the package and distribute system. The products also need to be supported by product at-tributes that show their environmental friendliness, for example the existence of an eco-friendly certificate. In addition, it also needs to be supported by promotional activities that also have environmental themes. This is consistent with research conducted by [7] which states that value has a positive and significant influence on purchasing decisions.

The second hypothesis shows that there is a significant influence between knowledge of consumer purchasing decisions in paying more. This means that higher knowledge will be followed by higher consumer decisions in paying more. In the process of purchasing a product, consumers tend to consider several product attributes, such as brand, quality, price, and so on. Consumers of green marketing products who have awareness and know environ-mentally friendly products and the application of environmental regulations will consider environmentally friendly aspects of a product. These consumers are often called "green orientation" which are predicted to increase in the future. They will choose environmentally friendly products even though the prices are relatively expensive [4]. This is consistent with research 
consum-er to willingness to pay more a consumer for green consumerism products.

\section{REFERENCES} a significant effect on consumers' decisions to pay more. The higher consumer attitudes, the higher the purchasing decisions. The results of this study indicate that consumer attitudes are a very important factor in the consumer decision-making process. This is illustrated by respondents' positive perceptions of satisfaction, level of pleasure, confidence consumers who buy The Body Shop products so that it affects the willingness to buy. Buying interest has a significant influence on the formation of purchasing decisions and environmentally friendly products. For this reason, owners need to create concepts or programs that can help consumers or customers to have an interest in environmentally friendly products. This is consistent with research con-ducted by [9] which states that consumer attitude has a positive and significant influence on purchasing decisions.

\section{CONCLUSION}

This study uses multiple linear regression analysis, to see the effect of independent variables, such as value, knowledge, and attitude to dependent varia-ble willingness to pay more. The result of research stated that simultaneously there is a significant influ-ence between values, knowledge, attitude a
[1] Ginsberg, J.M. \& Bloom, P.N. 2009. Choosing the right green marketing strategy. Managenet Review 46(1).

[2] Junaedi, J. 2005. Pengaruh kesadaran lingkungan pada niat beli produk hijau: Studi perilaku konsumen berwawasan lingkungan. Benefit. 9(2).

[3] Junaedi, J. 2006. Pengembangan model perilaku konsumen berwawasan lingkungan di Indonesia: Studi perbandingan kota metropolitan dan non metropolitan. Jurnal Ekonomi dan Bisnis 21(4).

[4] Laroche, M., Toffoli, R., Kim, C. \& Muller, T.E. 2001. The influence of culture on pro environmental knowledge, attitudes, and behaviors: A canadian perspective. Association for Consumer Research 23.

[5] Bui. 2005. Environmental marketing: A model of consumer behavior.

[6] Ghozali. 2015. Structural equation modelling: Teori, konsep, \& aplikasi dengan program lisrel 8.54.

[7] Harun, A., Lily, J., Sulong, R. \& Kong, W. 2014. The influence of consumer's perception of green products on green purchase intention. International Journal of Asian Social Science 4(8): 924 - 939

[8] Bisschoff, C.A. \& Liebenberg, P. 2016. Identifying factors that influence University South Africa: 174 - 189

[9] Anvar, M. \& Venter, M. 2014. Attitudes and purchase behavior of green products among generation y consumers in South Afrika. Mediteranian Journal of Social Science 5(21). Proceedings of the Annual Meeting of the Association of Collegiate Marketing Educators: 20-25 green purchasing behavior in South Africa. Journal of North West 